\title{
Effectiveness of renewable energy incentives on sustainability: evidence from dynamic panel data analysis for the EU countries and Turkey
}

\author{
Gülden Bölük ${ }^{1} \cdot$ Ramazan Kaplan ${ }^{2}$
}

Received: 30 September 2021 / Accepted: 23 November 2021 / Published online: 2 December 2021

(c) The Author(s), under exclusive licence to Springer-Verlag GmbH Germany, part of Springer Nature 2021

\begin{abstract}
We aim at analyzing the influence of incentive policies on renewable energy deployment in European Union countries and Turkey over the 2000-2018 period. Applying both panel fixed effect and the dynamic panel estimation methods, we compared the results of these two different techniques. Moreover, we included "net metering" that has not been analyzed before, in our policy toolkit, that includes a large number of incentives. Our data cover longer time series than the previous studies in the literature, and it provides new results of different renewable energy policies and drivers for analyzed countries. Empirical findings show that while grants, Research and Development, tax, certification, and policy support have positive and statistically significant impacts on the renewable energy capacity, direct investments, loan, and net metering instruments have no stimulating effect on the renewable energy deployment. These results indicate the deterrent impact of regulations and direct investments on capacity of electricity generated from renewable energy. Moreover, our estimation results reveal that fossil energy consumption, nuclear energy, and GDP are important drivers of renewable energy deployment while net import (energy security) and $\mathrm{CO}_{2}$ emissions are not. Our study highlights the importance of research and development activities, tax incentives, and efficient policy design in transition to green economy in the countries analyzed. Following the detailed discussion of the results, possible policy implications are presented at the end of the study.
\end{abstract}

Keywords Renewable energy incentives $\cdot$ Fixed effect $\cdot$ Dynamic panel $\cdot$ EU countries $\cdot$ Turkey

\section{Introduction}

Global warming and increasing environmental degradation became important concern in the world in the last 3 decades. Since increasing greenhouse gases (GHGs) pose a global problem, the world countries seek for solutions at global level organizing meetings such as the "United Nations Conference on Climatic Change in 1992" and "Paris Conference in 2015." The Kyoto Protocol in 1997 and Paris Agreement

Responsible Editor: Ilhan Ozturk

Gülden Bölük

guldenboluk@akdeniz.edu.tr

Ramazan Kaplan

ramazankaplan79@hotmail.com

1 Department of Economics, Akdeniz University, Antalya, Turkey

2 Akdeniz University, Social Science Institute, Antalya, Turkey in 2016, which are the two important agreements resulting from these conferences, aim at mitigating the GHG emissions and keep the rise in global average temperature to well below $2{ }^{\circ} \mathrm{C}$. According to those agreements, each country must design a specific plan to fight against global warming (UNFCC 2020; Wang et al. 2022). Moreover, to ensure energy supply security and mitigate the environmental deterioration, United Nations (UN) adopted a universal call to ensure "access to affordable, reliable, sustainable, and modern energy for all" (7th Sustainable Development Goal-SDG7) (UN 2021; Ioan et al. 2020). Many countries try to diversify their energy supply by developing alternative energy sources such as wind, solar, and biomass due to most worrying environmental problem-climate change-in the world and oil crises occurred during the 1970s. In this context, initiatives have been observed in recent years and investments are accelerated in the renewable energy (hereafter RE) sector in many countries including the European Union (EU) countries. It is expected that the replacement of fossil fuels with RE technologies will play a key role 
in achieving energy security, environmental stability, and SDG7 (Aquila et al. 2017; Murshed et al. 2020, Al-mulali et al. 2015, 2016.

The RE has become an alternative to fossil fuels and nuclear energy; however, there are also controversial arguments about whether production of the RE should be encouraged with policies or not, if so, which incentive tools should be utilized (see Harjanne and Korhonen 2019). In this respect, it is important to analyze the effectiveness of implemented RE policies used in promoting the RE installed capacity. The International Energy Agency (IEA) (2020) has recently emphasized on the negative impacts of Covid-19 pandemic for its decelerating role on the RE investment in the world. However, it is also highlighted by the IEA that the share of RE in electricity generation improved following the lockdown measures. Hence, to examine the effectiveness of RE, incentives has gained more importance than ever. As stated by Liu et al. (2019), there are numerous studies that qualitatively evaluate the effectiveness of RE policies; however, few numbers of quantitative work have discussed the role of RE policies in the literature.

We focus on the EU countries in this paper as Joint Research Centre JRC (2019) and indicate them as the top 6 emitters in the world along with China, the USA, India, Russia, and Japan. The EU countries have so far consumed $80 \%$ of the total amount of fossil fuel and emitted $67.5 \%$ of the total $\mathrm{CO}_{2}$ emissions globally. Despite the downward trends in GHG emissions, $\mathrm{CO}_{2}$ emissions per capita in $\mathrm{EU}$ are still above the world average (JRC 2019). The EU countries have very enthusiastic RE policies, since they desire to be at the leading position in research, development, and consumption of renewables in the world (Wang and Zhan 2019). For example, as stated by Borawski et al. (2019), the EU has $30 \%$ of the patents regarding RE in the world. According to the EC (2020) data, the share of the RE nearly doubled over the 2004-2018 period in the EU. As a candidate county, Turkey plans to meet two-thirds of its electricity consumption from RE sources by 2023 as well (PWC 2012). As EU countries have made significant progress in promoting RE, their experience will guide other countries in the world. Moreover, since Turkey is a candidate country to EU membership, findings of the paper will contribute to harmonization of regulations in membership process. Moreover, boosting RE sources contributes to energy security and promotes sustainable economic development. Hence, the current paper focuses on the EU countries and Turkey. Furthermore, although there is a general consensus related to the critical role of RE sources in mitigating the global warming in the relevant literature, however, it is still considered to be economically and technologically disadvantageous (Liu et al. 2019; Aquila et al. 2017).

The current paper analyzes how the RE policy tools (incentives) affect the installed capacity of the RE sources (electricity from solar, wind, geothermal) in EU countries and Turkey. There are few empirical studies that examine the role of RE incentives in RE deployment for EU in the literature. These studies either investigated the impacts of incentive schemes on RE capacity using panel data analysis (see Nicolini and Tavoni 2017; Marques et al. 2010; Jenner et al. 2013; BolkesjØ et al. 2014; Kilinc-Ata 2016) or examined the drivers of RE through dynamic panel data (see Zhang 2013; Marques and Fuinhas 2011a) and reveal controversial results. In the case of Turkey, there is no research paper that empirically analyzes the effectiveness of RE policies in RE deployment. Unlike the previous studies, we employ both panel data methods and compared the obtained results to strengthen empirical findings. In this context, findings of the current paper will contribute to design effective RE policies as a significant component of national planning in both developed and developing countries (Bölük 2013; Murshed et al. 2021).

Our contribution to the previous literature is manifold: first, this paper is the first attempt, to the best of our knowledge, that analyzes the effect of "net metering" incentive on installed capacity. Although "net metering" has been already put into force in $13 \mathrm{EU}$ countries, no study empirically has examined the role of it in RE deployment yet. Second, existing studies either analyze the effectiveness of implemented RE incentive schemes (with some control variables and static panel data) or attempt to determine factors that affecting the installed RE capacity with dynamic approach. Against the previous studies, this study employs both static and dynamic panel data and compares the obtained results of two models. Dynamic panel data approach allows us to investigate the impact of different factors on the RE for different countries in the EU, while controlling the persistent effect of lagged RE variable. Moreover, few numbers of empirical studies, which employed dynamic panel approach, focused on the EU countries (only Marques and Fuinhas 2011b). As mentioned above, current paper extends the study of Marques and Fuinhas (2011a), by employing two different panel data models for European countries and comparing the obtained results. Third, the time interval of our dataset is longer, covering the period of 2000-2018, and contains more recent observations compared to the previous studies in the literature.

In this research paper, we are looking for answers to the following issues that will contribute to efficient energy policy design and sustainable economic development:

1. Are implemented RE incentives really fostering RE deployment and/or installed RE capacity in the analyzed country? If yes, which incentive mechanisms are effective? There are several studies focusing on these questions; however, they reveal controversial results. Therefore, the results of current study will contribute to 
better understanding of the effectiveness of incentives and effective energy policy formulation.

2. Are $\mathrm{CO}_{2}$ emissions, GDP, nuclear power, electricity consumption, etc. fostering RE deployment or not? The current study employs two different panel data analysis to provide insights about these drivers of RE capacity development.

3. Among the others, is "net metering" stimulating the installed RE capacity in the analyzed country? Previous empirical studies provided no information on the effectiveness of this RE incentive tool in the literature.

The rest of the paper is organized as follows. "Current status of RE in the European Union and Turkey" section discusses the development of RE in EU and Turkey as well. "Literature Review" section reviews the related literature discussing the effectiveness of RE incentives. "Data and methodology" section presents the data and econometric methodology adopted. "Results" section reports the results of the panel data analysis, and the final section concludes.

\section{Current status of RE in the European Union and Turkey}

The first conceptual framework for RE in Europe and targets about its share in the EU gross energy consumption were proposed in the "White Paper" and the "Green Paper" published by the European Commission in the 1990s. However, the insufficient progress in RE capacity until the 2000s led the EU to prepare the first directive. Actions in the EU, related to renewable energy, commonly have been driven by the directives. The first two directives published in 2001 and 2003 state that the production and consumption of RE sources are important for sustainable development. The third directive (2009/28/EC) was published in 2009 as a revised version of the first two directives. This directive establishes an overall policy to generate energy from RE sources in the
EU. It requires the EU to meet at least $20 \%$ of its total energy requirement with RE by 2020 - to be achieved through the attainment of individual national targets. According to aforementioned directive, the EU countries must meet minimum binding target of $10 \% \mathrm{RE}$ share in the transportation sector by 2020, as well (EC 2009).

The fourth directive is entitled as the "Revised Renewable Energy Directive" published on 30 November 2016. Within the scope of this directive, it is requested from the member states to make the EU a world leader in RE production and to increase its share in final energy consumption to $27 \%$ by 2030. As a part of "Clean Energy for all Europeans" plan, the revised RE directive 2018/2001/EU came into force in December 2018. Revised RE directive aimed at keeping the $\mathrm{EU}$ as a global leader in RE by encouraging member states to meet its GHGs commitments agreed under the Paris Agreement. The Europe 2030 target has been planned through "2030 Climate and Energy Framework." In this framework, the Europe 2030 target share for RE is "at least $32 \%$ of final energy consumption with a clause for a possible upwards revision by 2023." Moreover, $40 \%$ cuts in GHG emissions (from 1990 levels) and 32.5\% improvement in energy efficiency was established in EU by 2020 (EC 2018).

Within the framework of these directives, the EU countries have been obliged to make a "National Action Plan (NAP)." Under NAP, member states must submit their progress on RE to the European Commission in 2-year reports. The European Commission must monitor the development and prepare the progress reports of the member states. Since member states in EU have different energy sources and different energy markets, NAPs are also different in terms of the content.

Fig. 1 is prepared using the statistics at IEA database and it shows how EU has replaced fossil fuels with RE since 2000. The European Commission reports that the share of EU energy obtained from RE sources in final energy consumption reached to $18 \%$ in 2018 that is more than double of the relevant amount in 2004 (8.5\%). The share of RE in
Fig. 1 EU electricity generation by source, 2000-2018. Source: IEA database, 2020
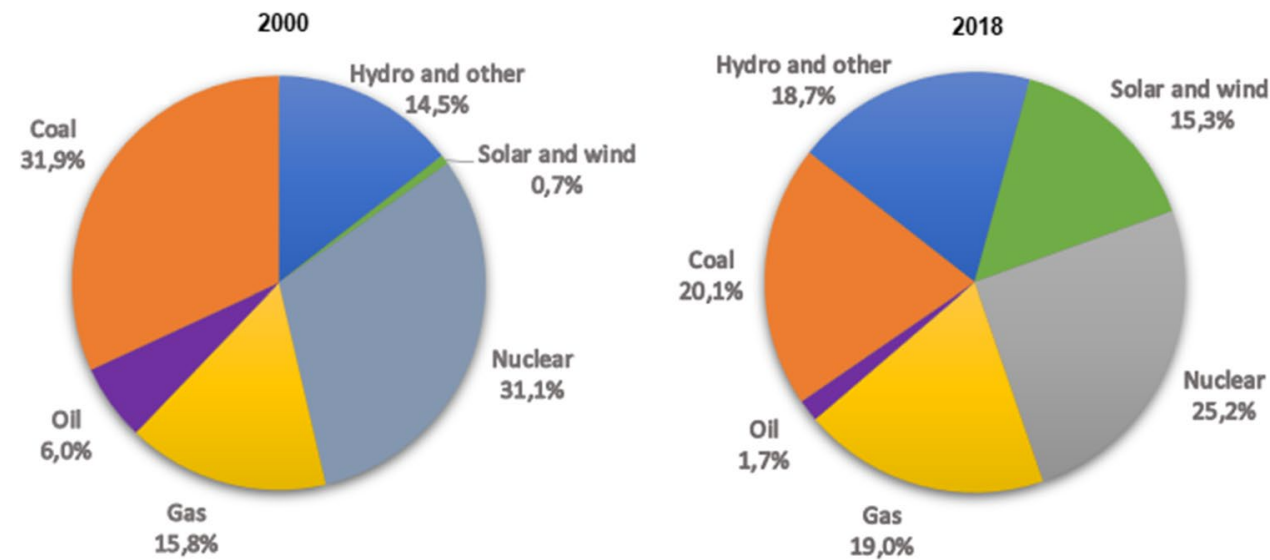
overall final consumption of energy is one of the key indicators of the European 2020 energy strategy (EC 2018).

Since the 2000s, as an EU candidate country, Turkey has started to introduce regulatory arrangements of the energy market. In Turkey, the rate of dependency increases with each passing year due to the increasing demand for energy. Foreign dependency in energy consumption has increased the importance given to the issue of energy supply security and has made it necessary to formulate energy supply strategies and to be implemented by supporting them with energy policies. The most important development regarding RE has been with the enactment of the Law on the Use of RE Resources for the Purpose of Electric Energy Production (YEK), dated 10.05.2005 and numbered 5346. With this law, what are the RE sources are defined and some incentives have been brought to these sources. The 11th Development Plan (DP- in 2019) constitutes the roadmap for RE deployment in Turkey. In this DP, it is envisaged that share of RE will rise to 38.8\% until 2023 (Erdin and Ozkaya 2019). Therefore, the RE investments would play important role in mitigating high import dependency and fulfilling the emission commitments for Turkey.

Table 1 presents the RE policies implemented in the EU and Turkey. Policy indicators are compiled from the IEA/ IRENA Policy and Measures (PM) database which comprises policy measures for the EU countries from 2000 onwards. As seen in Table 1, tax incentives, feed in tariff, loans, and obligations have been most adopted support schemes among the others. The incentive schemes will be discussed in detail under the Section "independent variables".

The EU countries have launched and implemented several incentive policies to be able to reach the desired level in RE (see Table 1). However, there is no strong empirical evidence showing that all incentive tools are effective. By using two different panel data model, the aim of this study is to examine the effects of RE incentive instruments in promoting the RE installed capacity in the EU and Turkey by using the data set over the 2000-2018 period.

\section{Literature review}

Given the policy relevance of this topic, some research studies have evaluated the drivers of RE development, from both a qualitative and quantitative perspective. Earlier studies generally analyzed the effects of one or few incentives or support mechanism on only electricity from renewables at country level. For example, Verbruggen (2004) have analyzed the impact of tradable certificate mechanism ${ }^{1}$ on $\mathrm{RE}$

\footnotetext{
${ }^{1} \mathrm{RE}$ incentive mechanisms will be discussed in detail in modelling part (under the Section "independent variables").
}

capacity in Flenders. Bird et al. (2005) have found that state tax and financial incentives including the state renewable portfolio standards (hereafter RPSs) developed the wind power in USA. Mitchell et al. (2006) and Wüstenhagen and Bilharz (2006) have analyzed the role of feed-in tariff (hereafter, FIT) and green power marketing on RE development in Germany. Lipp (2007) has compared the role of FIT and tradable green certificates in Denmark, Germany, and the UK and has found that FIT is a kind of cost-effective incentive for developing the renewable electricity. Dong (2012) has investigated the impact of incentive policies on wind power for 53 countries and found that FITs are more effective than renewable portfolio standard (RPS).

Empirical studies have become widespread after Menz and Vachon's (2006) preliminary work. In this study, Menz and Vachon (2006) have examined the role of wind power incentives in 39 states in the USA by using panel data. Their findings show that renewable portfolio standards accelerated the wind power generation. Similarly, Carley (2009) has focused on the 50 states of the USA over the period of 1998-2006 and found that RPSs is not a significant determinant of the share of RE generation but is positively related to the aggregate renewable electricity power generation.

Another strand of studies has carried out cross-country analysis to investigate the effectiveness of a set of incentives implemented to increase the RE capacity. For example, Polzin et al. (2015) have analyzed the effects of policy instruments on the diffusion of RE technologies using a panel data of OECD countries over the period of 2000-2011. Authors have found that monetary and fiscal economic incentives are important policy measures which positively affect the risk/ return profile of newly established RE projects. Moreover, market-based incentives (such as GHGs emission trading system) and supportive regulatory measures like codes and standards (especially RPS) have strong influence on RE investments. Liu et al. (2019) have examined the impact of RE policy incentives on RE deployment for 29 countries from the EU and OECD using a panel data set over the period of 2000-2015. Authors have classified these incentives into seven subgroups and four of them (market-based instruments, $R \& D$, fiscal and financial incentives, and policy supports) have been proved to be significant in the development of RE capacity. Moreover, three out of twelve specific policies, such as grants and subsidies, price policy, and strategic planning, stimulate the development of the RE capacity in analyzed countries. Nicolini and Tavoni (2017) have tested whether policy supports have been effective in developing RE capacity in the five largest European countries by using panel dataset over the period of 2000-2010 and found that FIT is a much more effective incentive than the tradable green certificates and a 1\% (1 Euro cent) rise in FIT increases the renewable electricity production capacity around $18-26 \%$. 


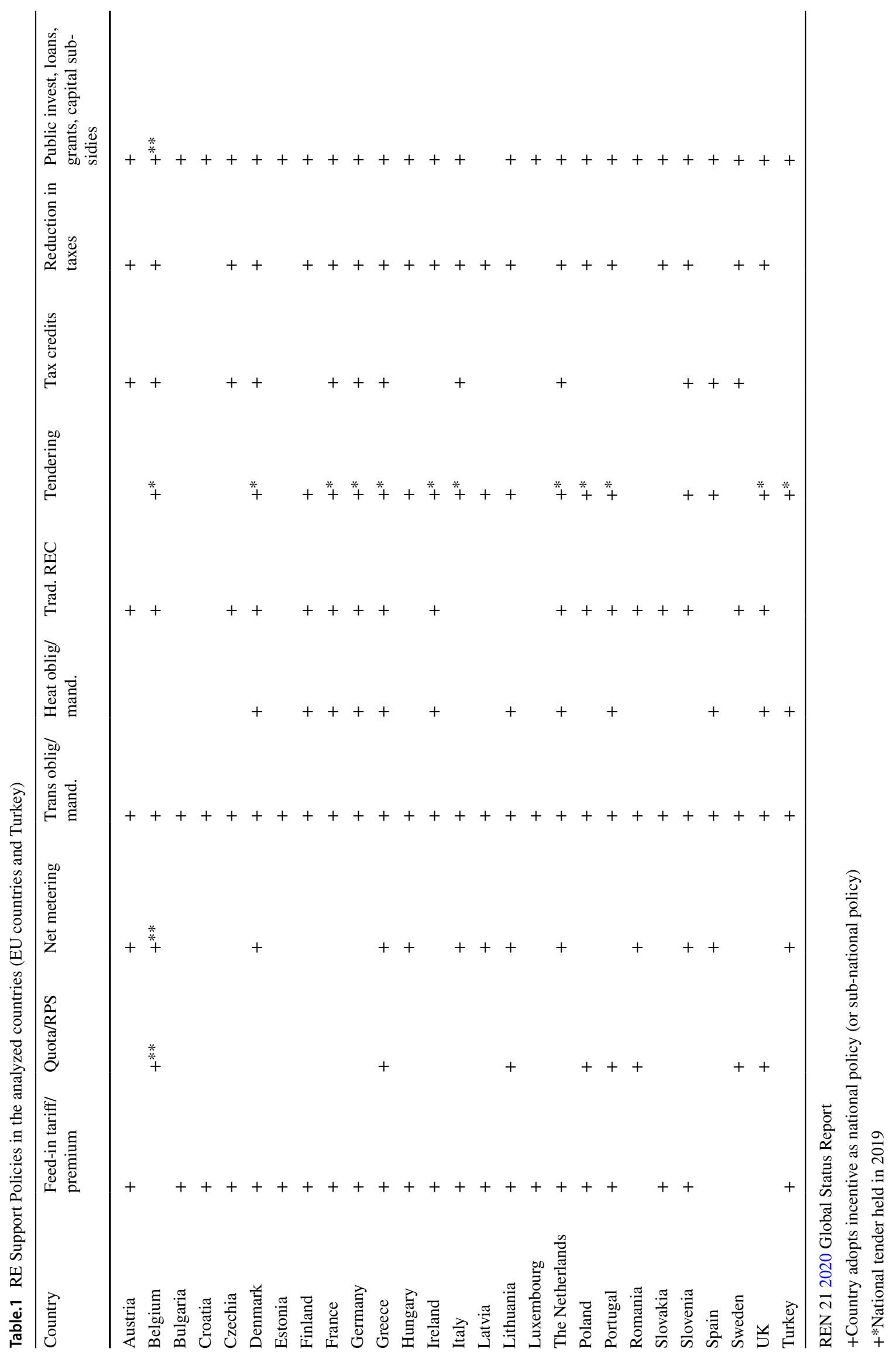


Since the EU wants to become the global leader in RE by implementing ambitious policies, some relevant studies in the literature have carried out analysis especially for the European countries. For example, Marques et al. (2010) analyzed the stimulating factors behind the RE utilization in EU countries using panel data set covering the period of 1990-2006. Authors confirmed that prices of fossil fuels (oil, natural gas, coal), dependency on fossil fuels, income, and aggregate energy utilization positively affect the RE consumption in the EU countries. Moreover, continuous commitments also have positive effect on the RE development in the EU. Interestingly, they could not find any significant relationship between $\mathrm{CO}_{2}$ and $\mathrm{RE}$ use in these countries. Similarly, Marques and Fuinhas (2011b) have examined the factors affecting the development of RE using quantile regression techniques for $21 \mathrm{EU}$ countries comparing two time periods (1990-1998, 1999-2006). However, authors have found contradicting results with their previous study analyzing the same EU countries. For example, prices of fossil fuels have been found insignificant for the $\mathrm{RE}$ use and $\mathrm{CO}_{2}$ emissions negatively affect the RE deployment. By using panel data set covering the 1990-2007 for 22 EU countries and Turkey, Marques and Fuinhas (2011a) empirically evaluated the efficiency of public policy supports of renewables in renewable use and concluded that "incentive/subsidy" policies such as FIT and policy process such as strategy planning have been effective devices in fostering renewables. However, quota obligations, product labelling, R\&D programs, tradable certificates, and pollution have not been the key incentives to stimulate the RE. Jenner et al. (2013) have examined the effectiveness of RE energy incentives and market characteristics in stimulating the RE for 26 European countries. Authors have found that price level of electricity and electricity generation cost (policy design features and market characteristics) are more effective determinants of the RES-E than policy incentives and FIT does not stimulate the wind power. Finally, Kilinc-Ata (2016) empirically tested the effectiveness of four RE policy instruments for 27 countries in the EU and 50 states in the USA. Her findings have pointed out the effective mechanisms for the RE installed capacity as FITs, tenders, and tax incentives, but not the quota.

Another strand focused on the macroeconomic and/or microeconomic drivers of RE deployment. For example, by using static panel data analysis, Gan and Smith (2011) analyzed the drivers for OECD countries and found positive relationship between GDPs per capita and RE installed capacity. However, changes in energy prices $R \& D$ policies, $\mathrm{CO}_{2}$ emissions, and government policies have been found insignificant. Similarly, Bengochea and Faet (2012) focused on EU countries during 1990-2004 period and found stimulating effect of $\mathrm{CO}_{2}$ emissions for RE. However, impact of fossil fuels price was found insignificant. Pfeiffer and
Mulder (2013) analyzed 108 developing countries and found positive relationship between real GDPs per capita, energy mix, participation in education, government policies, and per capita electricity production from RE sources. Ackah and Kizys (2015) analyzed oil producing African countries during the 1985-2010 period and found that GDP per capita, population, and capital formation increase the RE consumption in these countries. However, $\mathrm{CO}_{2}$ emissions and energy prices negatively affect the RE consumption. Using crosssectional ARDL, Li et al. (2020) demonstrated the positive role of eco-innovation and energy efficiency on RE deployment. Murshed et al. (2021) examined the role of regional trade integration on RE transition for South Asia and found unidirectional causal relationship from intra-regional trade shares to RE deployment. Irfan et al. (2021) examined the role of consumer-based factors on RE usage in Pakistan and found that perception of self-effectiveness, awareness of RE, and perception of neighbor's participation are significant factors for RE consumption.

To sum up, although majority of qualitative and theoretical studies have emphasized the positive effects of the incentives on the RE deployment, the number of empirical studies is insufficient in this field. Moreover, results of empirical studies are mixed and do not reveal clearly stimulating effect of all incentive policies. Therefore, the effectiveness of incentive policies on renewable electricity and/or energy remains unclear and inconclusive. In this consideration, testing the link between policy tools and RE deployment is critical for efficient policy designs. This paper aims at contributing to this research area analyzing the influence of incentive policies on (RE) deployment in the EU countries and the Turkey between 2000 and 2018. To the best of our knowledge, there has been no study that analyzed the effect of "net metering" incentive on RE production. Unlike the previous studies, current paper, however, investigates the effectiveness of this commonly used incentive on renewable capacity generation.

\section{Data and methodology}

\section{Research design}

The aim of our study is to reveal the impact of different policy measures and/or tools on the RES-E installed capacity in the EU countries and Turkey. For this purpose, two different panel data modelling are designed to examine whether the incentive schemes are effective in RES-E capacity development. We initially analyze a panel fixed effect model with country-specific time trends (presented in Eq. 1), followed by dynamic panel procedure (presented in Eq.2). The implemented incentive policies cannot increase the energy generation immediately since investment process such as wind 
turbine or solar panel installation and the legal authorization procedure could take a long time. For this reason, we take one lag of policy variables in the econometric model and used a dynamic framework. In this regard, to curb the problems that stem from the presence of endogeneity and heteroskedasticity, we have adopted Arellano-Bover/Blundell-Bond GMM estimator for dynamic panel model.

By using eleven different policy variables (including the net metering), we aim at measuring the impact of policies on a certain type of RE separately. We also include several control variables that may affect the relevant energy capacity. The selection of policy instruments and control variables included in the model are explained under Section "independent variables".

The time frame has been selected on the basis of data availability; however, our data period still covers the longer data period than the previous studies focusing on the RE in energy economics. We structured our data set according to different sectors of RE (Total RE sources, Wind, Solar, and Biomass) and various policy instruments implemented within the EU (see Fig. 2).

\section{Data}

RES-E capacity data have been obtained from the IRENA database. Policy (incentive) variables have been compiled from the IEA/IRENA Policy and Measures database. Control variables in our analysis are obtained from the US Energy Administration (EIA) and the World Bank. The entire data set covers the period of 2000-2018 for the EU countries and Turkey.

Table 3 presents the definition of variables and the descriptive statistics. These indicators of RES-E have been commonly used by scholars to examine the impacts of aggregated policy instruments in the literature (see Table 1 and 2).

As seen in Table 2, we have 513 observations for all kind of RE installed capacity. Among the others, wind energy has the highest mean.

\section{Model}

The recent studies focusing on the effectiveness of RE incentives have generally carried out panel data analysis. In the same way, we have employed a panel data model to analyze the link between policy incentives and RE deployment. Using a data set covering 2000-2018 period for the EU countries, we have initially employed a panel fixed effect model. Our data set covers 25 member states including Austria, Belgium, Bulgaria, Croatia, Czech Republic, Denmark, Estonia, Finland, France, Germany, Greece, Hungary, Ireland, Italy, Latvia, Lithuania, Luxembourg, the Netherlands, Poland, Portugal, Romania, Slovakia, Slovenia, Spain, and Sweden. Malta and Cyprus were excluded from the model because of having insignificantly small data. Panel fixed effect estimator is used since the unobserved heterogeneity is constant over time (Kilinc-Ata 2016) and renewable electricity capacity can be affected by unobserved characteristics. In addition to panel fixed effects, the dynamic panel data model is estimated as well. Dynamic panel data models contain the lagged of the dependent variable as one of the explanatory variables. In our case, we believe that the installed capacity of the previous periods may positively affect the RE capacity of the current period. This method yields more efficient parameter estimates than the i.i.d. error model in the traditional static fixed effect estimator by ensuring the following advantages: (i) it eliminates the individual non-observable
Fig. 2 Framework of variables (policy variables are classified based on IRENA)

\section{Policy Variables}

\begin{tabular}{|l|}
\hline Fiscal and financial incentives \\
Grants and subsidies \\
Taxes\&tax relief \\
Feed-in tariffs/premiums \\
Loans \\
\hline Market-based instruments \\
Green certificates \& \\
GHG emissions allowances \\
\hline Direct investments \\
\hline Policy support \\
\hline Regulatory instruments \\
RPS \& codes and standarts \\
\& other mandatory requirements \\
\hline Research, development and \\
deployment \\
\hline Net metering \\
\hline Tendering \\
\hline
\end{tabular}

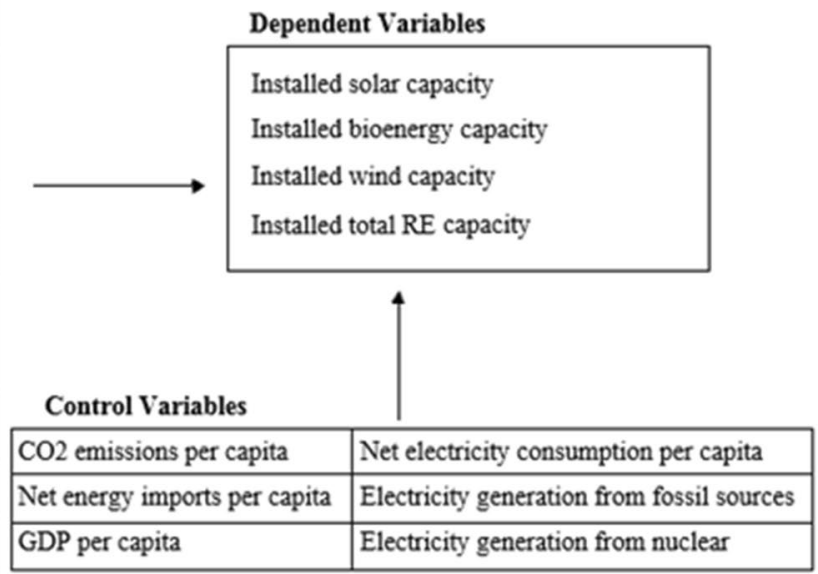


Table.2 Definition of variables, sources of data and descriptive statistics

\begin{tabular}{|c|c|c|c|c|c|c|c|}
\hline \multicolumn{2}{|l|}{ Variables } & Obs & Mean & Std. Dev. & Min & Max & Sources \\
\hline \multicolumn{8}{|c|}{ Dependent variables } \\
\hline BIOCAP & Bioenergy installed capacity (GWh) & 513 & 854.8 & 1461 & 0 & 9648 & IEA/IRENA \\
\hline SOLARCAP & Solar energy installed capacity (GWh) & 513 & 1571.4 & 5451.1 & 0 & 45181 & IEA/IRENA \\
\hline WINDCAP & Wind energy installed capacity (GWh) & 513 & 3132.4 & 7000.8 & 0 & 58843 & IEA/IRENA \\
\hline TOTALCAP & Total RE (excluding hydro) installed capacity (GWh) & 513 & 5604.1 & 13186 & 0 & 113711 & IEA/IRENA \\
\hline \multicolumn{8}{|c|}{ Independent variables } \\
\hline \multicolumn{8}{|l|}{ Policies } \\
\hline DIR & Direct investment & & & & 0 & 1 & IEA/IRENA \\
\hline FIT & Feed-in tariffs/premiums & & & & 0 & 1 & IEA/IRENA \\
\hline GRANT & Grants and subsidies & & & & 0 & 1 & IEA/IRENA \\
\hline LOAN & Loans & & & & 0 & 1 & IEA/IRENA \\
\hline TAX & Taxes \& tax relief & & & & 0 & 1 & IEA/IRENA \\
\hline CERT & GHG emissions trading $\&$ tradable certificates & & & & 0 & 1 & IEA/IRENA \\
\hline POL & Policy support & & & & 0 & 1 & IEA/IRENA \\
\hline REG & Regulatory requirements & & & & 0 & 1 & IEA/IRENA \\
\hline $\mathrm{R} \& \mathrm{D}$ & Research, development, and deployment & & & & 0 & 1 & IEA/IRENA \\
\hline MET & Net metering & & & & 0 & 1 & IEA/IRENA \\
\hline TEN & Tendering & & & & 0 & 1 & IEA/IRENA \\
\hline \multicolumn{8}{|c|}{ Control variables } \\
\hline NETIMP & Net energy imports per capita (toe) & 496 & 2.0 & 1.7 & -1.9 & 10.1 & IEA \\
\hline GDPP & GDP per capita (in billions US dollars, constant 2010) & 513 & 31643.5 & 21616.2 & 3984.8 & 111968.4 & WB \\
\hline NETCON & Net electricity consumption per capita (MWh) & 513 & 6.0 & 3.2 & 1.5 & 16.6 & IEA \\
\hline $\mathrm{CO} 2$ & $\mathrm{CO}_{2}$ emissions per capita (metric tons) & 513 & 7.5 & 3.5 & 2.8 & 24.7 & EIA \\
\hline FOS & $\begin{array}{l}\text { Electricity generation from fossil sources (oil, gas, and } \\
\text { coal) (\% of total generation) }\end{array}$ & 513 & 55.1 & 26.9 & 1.1 & 150.8 & EIA \\
\hline NUC & Electricity generation from nuclear (\% of total generation) & 512 & 19.5 & 23.3 & 0 & 84.1 & EIA \\
\hline
\end{tabular}

effects of countries; (ii) it solves endogeneity among independent variables, since their lagged values are used as instrumental variables, (iii) it handles collinearity among variables; and (iv) it allows us to test whether installed RE capacity in the current period is significantly correlated with the previous renewable capacity (He et al. 2018; Marques and Fuinhas 2011a).

The variables incorporated into model are log-transformed to fix for the skewed distribution of both dependent and explanatory variables (Hair 2010). It is expected to see a positive effect for every subset of incentive measure on the installed capacity of RES-E. The components of the model are classified and presented in Fig. 2 as well.

Panel data model with one lag procedure is as following:

$R E C_{y i t}=\beta_{0}+\sum_{j=1}^{j} \beta_{j} P_{j y t-1}+\sum_{k=1}^{k} \delta_{k} K_{k i t-1}+d_{i}+d_{t}+\varepsilon_{y i t}$

In Eq. 1, dependent variable $R E C_{y i t}$ is the electricity generated from RE sources (RES-E) installed capacity. $y$ stands for the RE sources (bio, solar, wind, and total renewable), $i$ stands for the country, and $t$ for the year. As independent variables in the panel data model, we include different policy measures, plus some other control variables. These policy measures are represented by $\boldsymbol{P}_{y i t-1}$ that is a vector of explanatory variables. Incentive policies cannot increase the generation immediately or this process could take up to 1 or 2 years. The reason for the delay is that investment process such as wind turbine or solar panel installation and the legal authorization procedure could take a long time. For this reason, we take one lag for applied policies and other control variables in current study. $j$ represents a type of policy measure such as feed-in tariffs, grants and subsidies, loans, taxes, tradable emissions certificates, policy support, regulatory requirements, R\&D, net metering, and tendering. We incorporated several variables that explain economic and political aspects, as well as energy-specific considerations that may affect the production of RE. Those coefficients of control variables are as shown by $\delta_{k}$, where $K$ is a vector including different control variables such as the logarithm of net energy imports per capita, the logarithm of GDP per capita, the logarithm of $\mathrm{CO}_{2}$ emissions per capita, the logarithm of net electricity consumption per capita, and the logarithm 
of electricity generation from fossil sources and nuclear. We included country dummy $\left(\mathrm{d}_{\mathrm{i}}\right)$ and time dummy $\left(\mathrm{d}_{\mathrm{t}}\right)$ into model as well. $\varepsilon_{y i t}$ is the identically independently distributed error term with the variance $\sigma^{2}$.

In different models, we use several dependent variables such as the installed total RE capacity and other RE capacities (see Fig. 2) to analyze the impacts of different incentive tools (economic instruments, regulatory instruments, policy supports, etc.) on RE deployment.

The current research paper also tests whether there is a persistence effect in installed RE capacity. There may be positive relationship between installed capacity in the previous $\left(\mathrm{REC}_{\mathrm{t}-1}\right)$ and current periods $\left(\mathrm{REC}_{\mathrm{t}}\right)$ since these large investments cannot be a decision for months or even for a year (Beck and Joshi 2015). Therefore, we estimate Eq. 2 using a dynamic approach called generalized methods of moments (GMM). Similar to Eq. 1, we have included some common economic and political variables such as GDP per capita, net electricity consumption per capita, $\mathrm{CO}_{2}$ emissions per capita, net energy imports per capita, and electricity generation from fossil sources and nuclear as controls.

As we mentioned before, dynamic panel data estimation process employs lags of dependent variables to be explanatory variables. By doing so, lagged values of the dependent variables become instruments to control endogeneity. Hence, we use the generalized methods of moments (GMM) to obtain efficient and consistent results under the presence of different kinds of endogeneity (for example, endogeneity of lagged dependent variable and other potentially endogenous explanatory variables). Moreover, we avoid unnecessary data loss. Therefore, this method improves the heteroskedasticity problem and creates efficient and unbiased results (Kukenova and Monteiro 2008; Beck and Josji 2015):

$R E C_{y i t}=R E C_{y i t-1}+\sum_{k=1}^{k} \delta_{k} K_{k i t-1}+u_{y i t}$

The equation for the model is a modified version of Arellano-Bover/Blundell-Bond GMM dynamic panel data and helps us to understand how economic variables and variables related with energy security and environment (e.g., GDP, $\mathrm{CO}_{2}$ emissions, energy consumption, and nuclear energy) affect the installed RE capacity in the EU countries. The model covers the AR(1) and AR(2) test to find evidence of serial correlation of the error term. If a country has a dependency on energy imports, we expect to confirm that its investment in renewable resources has increased. We expect a rise on RE use and capacity when income level is rising because a greater level of income means greater potential source for RE investments. A vast majority of literature suggests that environmental concerns promote the widespread use of RE, so we expect to conclude that greater $\mathrm{CO}_{2}$ emissions mean greater RE capacity. Finally, as the electricity generation from fossil sources and nuclear increases, we expect a decrease at the share of renewables.

\section{Dependent variable}

Dependent variable for overall econometric model is measured as total installed capacity (in MW) of RES-E in a specific country and year in a specific subsector such as wind, solar, and biomass. Although some studies used the RE generation, added capacity, or percentage of RE in total energy supply as an indicator of the RE development (see Table 3), we use RES-E capacity values since capacity is accepted as better proxy for RE deployment (see Popp et al. 2011; Polzin et al. 2015).

As presented in the Table 3, installed capacity has been commonly used as an indicator and/or measure for RES-E in the literature.

\section{Independent variables}

The RE policy instruments $\left(P_{y i t-1}\right)$ are critical explanatory variables that include direct investment, feed-in tariffs/premiums, grants and subsidies, loans, taxes and tax relief, GHG emissions trading and tradable certificates, policy support, regulatory requirements (codes and standards, monitoring and obligation schemes), research and development and deployment, tendering, and net metering measured at country-year level. The data of those variables are obtained from IEA/IRENA database. Policy instruments are represented by dummy (binary) variables that take 1 if a country adopted the relevant policy instrument (such as FIT, taxes, and R\&D) and zero otherwise. In other words, 11 policy variables will take the value of 1 after the implementation of policy and 0 before. In the current study, dummy variables
Table.3 Dependent variables in literature

\begin{tabular}{ll}
\hline Dependent variables & Reference \\
\hline Installed capacity & Dong 2012; Bolkesjø et al. 2014; Liu et al. 2019; Menz and \\
& Vachon 2006; Polzin et al. 2015 \\
RE \% of total energy supply & Carley 2009; Aguirre and Ibikunle 2014; Marques et al. 2010; \\
& Marques and Fuinhas 2011b \\
RE\% of total energy capacity & Kilinc-Ata 2016; Shrimali and Kniefel 2011 \\
Added capacity & Jenner et al. 2013; Zhang 2013 \\
RE generation & Carley 2009; Nicolini and Tavoni 2017; Kim and Heo 2016 \\
\hline
\end{tabular}


are preferred to "accumulated number of RE policies and measures," since having a greater number of policies does not necessarily mean that countries apply effective/and or successful RE policies.

As mentioned on Table 4, there has been no study that analyzed the effect of "net metering" incentive on RE production. This paper, however, evaluates the impact of this commonly used incentive on renewable capacity generation. As presented in Table 1, 13 countries have already included this instrument into their incentive policies in the EU.

Before proceeding with the analysis, it would be useful to give information on the policy instruments in detail to better understand the interaction between RE policies and the RE development.

Grants and subsidies: Grants are amounts that generally do not need to be repaid but must be used for specified purposes. Grants for RE are normally awarded by local governments, public organizations, or non-profit organizations to fund feasibility studies, research and development activities, system installation and operation, and business development activities. Grants can also be combined with mixed policies, and subsidized loans to support the expansion of RE and energy efficiency. Apart from the "grants," subsidies refer to direct aid, tax cuts, and other special assistance that governments give businesses to reduce operating costs in the long term. The main rationale for subsidizing is to encourage costly investment for businesses. Capital subsidies in RE can be used to help create a level playing field with conventional energy technologies and lower initial capital costs (IRENA 2018: 71-72).

Tax exemption is generally applied as a fiscal incentive measure (see Fig. 2) to boost the RE investments in energy sector. Another incentive tool in tax policy is tax credits. Tax credits on purchase and installation of RE equipment facilitate the penetration of RE deployment into the market. A tax credit is a sum of money that taxpayers can deduct from taxes they are obliged to pay their government. The advantage of tax credit is to reduce the total debt burden and fossil fuel utilization. For example, a carbon tax increases the cost burden for burning of fossil energy and facilitates the investments in RE (Abolhosseini and Heshmati 2014; IRENA 2018:71).

Feed-in tariff/premium payment is a policy that specifies a payment per unit (e.g., USD per KWh) for RE generators with long-term contracts, usually for a fixed period of time (15-25 years). The fixed price guarantee (Feed-in Tariff)

Table.4 Independent variables in the literature

\begin{tabular}{|c|c|}
\hline Independent variables & Reference \\
\hline \multicolumn{2}{|l|}{ Policy variables } \\
\hline DIR & Aguirre and Ibikunle 2014; Liu et al. 2019 \\
\hline FIT & $\begin{array}{l}\text { Bolkesjø et al. 2014; Dong 2012; Aguirre and Ibikunle 2014; Liu et al. 2019; Marguez et al. 2019; Kim and Heo 2016; } \\
\text { Zhang 2013; Nicolini and Tavoni 2017; Polzin et al. 2015; Kilinc-Ata 2016; Johnstone et al. 2010; Jenner et al. } 2013\end{array}$ \\
\hline GRANT & Aguirre and Ibikunle 2014; Liu et al. 2019; Menz and Vachon 2006; Nicolini and Tavoni 2017; Polzin et al. 2015 \\
\hline LOAN & Aguirre and Ibikunle 2014; Liu et al. 2019; Menz and Vachon 2006; Polzin et al. 2015 \\
\hline TAX & Liu et al. 2019; Polzin et al. 2015; Kilinc-Ata 2016; Johnstone et al. 2010 \\
\hline CERT & Aguirre and Ibikunle 2014; Liu et al. 2019; Nicolini and Tavoni 2017; Polzin et al. 2015; Johnstone et al. 2010 \\
\hline POL & Aguirre and Ibikunle 2014; Polzin et al. 2015 \\
\hline REG & $\begin{array}{l}\text { Bolkesjø et al. 2014; Dong 2012; Aguirre and Ibikunle 2014; Shrimali and Kniefel 2011; Liu et al. 2019; Menz and } \\
\text { Vachon 2006; Kim and Heo 2016; Polzin et al. 2015; Kilinc-Ata 2016; Johnstone et al. 2010; Carley } 2009\end{array}$ \\
\hline $\mathrm{R} \& \mathrm{D}$ & Liu et al. 2019; Polzin et al. 2015; Johnstone et al. 2010 \\
\hline MET & - \\
\hline TEN & Bolkesjø et al. 2014; Kilinc-Ata 2016 \\
\hline \multicolumn{2}{|l|}{ Control variables } \\
\hline NETIMP & $\begin{array}{l}\text { Don, 2012; Aguirre and Ibikunle 2014; Marques et al. 2010; Kim and Heo 2016; Nicolini and Tavoni 2017; Kilinc-Ata } \\
\text { 2016; Jenner et al. } 2013\end{array}$ \\
\hline GDPP & $\begin{array}{l}\text { Bolkesjø et al. 2014; Dong 2012; Aguirre and Ibikunle 2014; Shrimali and Kniefel 2011; Liu et al. 2019; Marques et al. } \\
\text { 2010; Kim and Heo 2016; Nicolini and Tavoni 2017; Polzin et al. 2015; Kilinc-Ata 2016; Carley 2009; Jenner et al. } \\
\text { 2013. Gan and Smith (2011), Pfeiffer and Mulder (2013), Ackah and Kizys (2015) }\end{array}$ \\
\hline NETCON & $\begin{array}{l}\text { Bolkesjø et al. 2014; Dong 2012; Aguirre and Ibikunle 2014; Liu et al. 2019; Marques et al. 2010; Marguez et al. 2019; } \\
\text { Kim and Heo 2016; Polzin et al. 2015; Kilinc-Ata 2016; Carley } 2009\end{array}$ \\
\hline $\mathrm{CO}_{2}$ & $\begin{array}{l}\text { Dong 2012; Aguirre and Ibikunle 2014; Liu et al. 2019; Marques et al. 2010; Kim and Heo 2016; Nicolini and Tavoni } \\
\text { 2017; Polzin et al. 2015; Kilinc-Ata 2016, Bengochea and Faet } 2012\end{array}$ \\
\hline FOS & $\begin{array}{l}\text { Bolkesjø et al. 2014; Aguirre and Ibikunle 2014; Shrimali and Kniefel 2011; Marques et al. 2010; Marguez et al. 2019; } \\
\text { Nicolini and Tavoni 2017; Carley 2009; Jenner et al. } 2013\end{array}$ \\
\hline NUC & Bolkesjø et al. 2014; Aguirre and Ibikunle 2014; Marques et al. 2010; Marguez et al. 2019; Jenner et al. 2013 \\
\hline
\end{tabular}


is an incentive mechanism in which the RE generators are guaranteed to purchase their electricity at a fixed price per $\mathrm{kWh}$. In the feed-in premium policy, a premium guarantee is provided for the electricity obtained from renewable sources, that is determined slightly above the market price (REN21 2019: 244). Among the others, FITs are the commonly used support mechanism to accelerate renewable investments in the world. According to the Global Status Report by (REN21, 2020), around 113 countries had used FIT policy in 2019.

Loans: One of the biggest obstacles to investments in $\mathrm{RE}$ is given to finance the high initial capital costs of RE projects in the world. Financing assistance in the form of low-interest, long-term loans and loan guarantees plays an important role in the development of RE by reducing the cost of capital and effectively reducing the average energy cost per unit and investment risk (Assmann et al. 2006: 96).

Carbon pricing is a mechanism that tries to shift the burden of damage caused by carbon back to those responsible for it and those who can reduce it. There are two basic carbon pricing systems: emission trading systems (ETS) and carbon taxes. In the emission trading system, a limit (or an upper limit) is set for the total greenhouse gas emissions of greenhouse gas emitting facilities and enables low emission industries to sell their surplus allowances to firms that emit higher amounts. The ETS application sets a market price for GHG emissions, creating favorable market for emission allowances. The carbon tax sets a price directly on carbon by imposing a tax rate on GHG emissions and/or on the carbon content of fossil fuels (WB 2019).

The renewable portfolio standard (RPS) is generally applied with FITs. However, while FIT mechanism is price based (fixed-price and premium price ensured by the government), the incentive of RPS is quantity based. RPS mechanism imposes an obligation on electricity generation and transmission companies that a predetermined part of the electricity they produce or sell is obtained from RE sources. In this application, a certificate is given to the generators for every megawatt hour of RE produced to meet mandatory quotas (REN21 2019: 247; IRENA 2018:62). Unlike the FIT mechanism, RPS incentive relies on the private market for its execution. Hence, it can be said that there is a price competition among the different types of RE technologies (Abolhosseini and Heshmati 2014).

Net metering is an electricity billing mechanism that generates some or all of its own electricity and allows consumers with electricity generators to use the excess electricity power they generate later. This kind of incentives is often adopted to encourage the development of small-scale rooftop solar PV systems, rarely small-scale wind turbines (REN21 2019: 61). By the end of the 2019, around 70 countries adopted net metering policies in the world. Turkey started to implement net metering program for solar energy systems under 10 kilowatts $(\mathrm{kW})$ of capacity in recent years (REN 21 2020).
The tender method (auction) is a procurement mechanism in which RE supply or capacity is requested competitively from vendors who offer bids at the lowest price they would like to accept. Offers can be evaluated on both price and non-price factors. Under a tender program, the regulatory authority declares that it wants to establish a specific capacity of a particular technology or technology suite. Project developers participating in auctions usually submit a bid with a price per unit electricity at which they can realize the project (REN21 2019:248; IEA 2011:35).

The regulatory policies aim to create environment that enables the switch to an efficient RE by binding legislations and setting targets. It includes government commitments to action such as roadmaps, action plans, and programs (REN 21 2020). Direct investments are related to infrastructure development such as integration of grids into RE by the government to minimize the transmission and fluctuation problems (Ding and Somani 2010:1-2). Generally, the RE investments are high-tech and costly investments. Therefore, technological support policies by governments are important to attract investments in this field. To encourage investment and innovation in the RE, governments need to focus not only on main climate policies, but also on broader investment conditions. Broadening the focus is particularly important in the context of the EU and the OECD countries as well as the ongoing reforms of incentive programs for the RE in emerging economies (OECD 2017: 12).

$R \& D$ support policies are crucial to develop new energy and efficiency technologies. R\&D investments encourage the radical innovations and develop the RE capacity in energy markets (Mihaylov et al. 2019).

All of the RE support policies implemented by the EU members and Turkey are shown in Table 4. FIT policies still play a crucial role in efforts to scale up renewable power in many of the EU countries, particularly to develop smallerscale projects and specific technologies. Although tradable energy certificates have been widely used among the EU members, Turkey has yet to start using this policy. Public investment, grants, and subsidies seem to be widely applied policy incentives by governments in many member states in EU.

\section{Results}

Before explaining our main findings, we report the results of econometric tests conducted for the presence of unobserved country and time effects, heteroskedasticity, serial correlation, and cross-sectional dependency. Based on the test results reported in Table 5, we see the necessity of the country and time effects in the models with different dependent variables. Therefore, we conclude that OLS estimation of all models would produce biased results. 
Moreover, it should be stated here that, since we have short panel data (micro panel, $\mathrm{N}>\mathrm{T}$ ), there is no need to do unit root test and cointegration (See Hayakawa 2017; Baltagi 2013). However, we apply Hausman test to determine whether it is appropriate to use the fixed effect (FE) or the random effect model for the estimation of those models. Test results support the use of FE for the models of solar, bio, and the total RE, while RE is suggested for the wind model.

After specifying the type of the model and estimator, we test for the heteroscedasticity, autocorrelation, and crosssectional dependency. Cross-sectional dependency is tested using Pesaran's CD test, Friedman's test, and Frees test. In order to test autocorrelation, we use Baltagi and Wu's locally best invariant (LBI) tests and the Durbin-Watson tests of Bhargava, Franzini, and Narendranathan. Finally, by applying modified Wald test, we check whether the heteroscedasticity problem exists or not for the fixed effect model.

We have found presence of heteroscedasticity, autocorrelation, and cross-sectional dependency for all the models as shown in Table 6. We used Driscoll-Kray nonparametric covariance estimator to correct these problems.

According to the correlation matrix (see Table 10 in the Appendix), explanatory variables are not generally and highly correlated. Assuming there is one lag (for explanatory variables), the fixed effect model (Eq.1) regression results will be as shown in Table 7 .

According to the results (see Table 7), FIT, while positively affecting the installed capacity of bioenergy and solar energy, it is not promoting the total RE installed capacity. Interestingly, when considering wind energy installed capacity, we also find a negative and significant coefficient of FIT for wind power. In addition, we find a significant positive impact of GRANT on wind and total RE capacity. LOAN displays a positive coefficient, which is however significant for wind power only. According to the results, while CERT has a positive coefficient for bioenergy and total $\mathrm{RE}$, it has no stimulating effect on solar and wind power. We also find a significant and negative relationship between REG and total RE and bioenergy. As expected, we find that TAX and R\&D has positive impact on RE capacity, except wind energy. POL positively effects the total RE capacity; however, it negatively influences the solar energy capacity.

Table.5 Unit-time effects and Hausman test

\begin{tabular}{lllll}
\hline & F & LR & LM & Hausman \\
\hline Solar & 22.49 & 247.60 & 402.28 & $515.87^{* * * *}$ \\
Bio & 31.06 & 364.47 & 1154.00 & $39.57^{* * *}$ \\
Wind & 36.92 & 401.16 & 1108.03 & 7.00 \\
Total RE & 35.87 & 397.35 & 1102.32 & $54.67 * * *$ \\
\hline
\end{tabular}

$* * *, * *$, and $*$, denote $1 \%, 5 \%$, and $10 \%$ significance level, respectively
Table.6 Tests for heteroscedasticity, autocorrelation and cross-sectional dependence

\begin{tabular}{lllll}
\hline & Bioenergy & Solar & Wind & Total RE \\
\hline Modified Wald & $5105^{* * *}$ & $3060^{* * *}$ & $25469^{* * *}$ & $14125^{* * *}$ \\
Pesaran's & $6.90^{* * *}$ & $10.68^{* * *}$ & $10.81^{* * *}$ & $12.24 * * *$ \\
Friedman's & $61.81^{* *}$ & 21.00 & $89.29 * * *$ & $48.18^{* * * *}$ \\
Frees & $9.50^{* * *}$ & $8.04 * * *$ & $11.00^{* * *}$ & $6.87 * * *$ \\
Bhargava-Franzini- & 0.84 & 0.51 & 0.78 & 0.82 \\
$\quad$ Narendranathan's & & & & \\
$\quad$ DW & & & & \\
Baltagi-Wu's LBI & 1.54 & 0.66 & 0.91 & 1.33 \\
\hline
\end{tabular}

$* * *, * *$, and $*$, denote $1 \%, 5 \%$, and $10 \%$ significance level, respectively

Unexpectedly, we observe a negative and significant coefficient for the regulatory instruments in stimulating the renewable deployment.

According to the results, MET and DIR policy are found to be ineffective for promoting RES-E capacity. The results from panel data analysis highlight that such incentives are ineffective in promoting RES-E installed capacity. Our results reveal that, among the others, R\&D, CERT, GRANT, TAX, and POL are very important incentive mechanisms to develop the total RE. This stimulating effect is reflected by a high level of statistical significance at the $1 \%$ and $5 \%$ significance level and positive coefficients. However, these incentives appear to have mixed results for different types of RES-E. Lastly, as reported in Table 7, while TEN has positive impact on wind power, it affects bioenergy installed capacity negatively.

The next issue is to investigate which control variables increase the renewables. Results in Table 7 show that NETIMP is significant for the solar and the total RE, but contrary to expectations, its sign is negative. NUC has positive relationship with total wind and bioenergy. While GDPP positively affects wind capacity, it negatively affects bioenergy capacity. $\mathrm{CO}_{2}$ emission displays a positive coefficient for the solar power, which is however negative for the wind power. Our results show that the other controls such as NETCON, FOS, and NUC are found to be poorly significant.

To simplify the analysis of the results of all estimated models, we show all the estimated coefficients and their significance in Table 8.

As seen in Table 8, among the others, only R\&D positively affects the production of both the total RE and all types of RE. Other RE policy incentives, however, have mixed results on the development of different RE capacity. If it is evaluated based on RE types, FIT, TAX, and R\&D incentives are found effective for the solar energy. For the wind power, GRANT, LOAN, POL, TEN, and R\&D incentives seem to be effective for capacity increase. Similarly, TEN, R\&D, TAX, FIT, and CERT are found important 
Table.7 The fixed effect model regression results with one lag (t-1)

\begin{tabular}{|c|c|c|c|c|c|}
\hline Variables & & Solar & Bioenergy & Wind & Total RE \\
\hline \multirow[t]{11}{*}{ Explanatory variables } & DIR & $-0.81(-1.39)$ & $-0.1(-1.42)$ & $0.06(0.3)$ & $-0.09(-1.34)$ \\
\hline & FIT & $0.57 *(1.85)$ & $0.13 * *(2.91)$ & $-0.43 *(-1.98)$ & $0.02(0.37)$ \\
\hline & GRANT & $0(0.01)$ & $-0.03(-0.28)$ & $0.96 * *(2.52)$ & $0.23 * *(2.95)$ \\
\hline & LOAN & $-0.31(-0.53)$ & $0.11(1.6)$ & $1.05^{* *}(2.81)$ & $-0.01(-0.08)$ \\
\hline & TAX & $1.81 *(2.01)$ & $0.43 * * *(3.53)$ & $-0.21(-0.66)$ & $0.41 * *(2.7)$ \\
\hline & CERT & $1.62(1.05)$ & $0.59 *(1.82)$ & $0.64(0.88)$ & $0.33 * *(2.58)$ \\
\hline & POL & $-0.88 *(-1.9)$ & $-0.15(-1.31)$ & $1.69 *(1.87)$ & $0.22 * *(2.27)$ \\
\hline & REG & $0.13(0.4)$ & $-0.23^{*}(-1.77)$ & $-0.09(-0.43)$ & $-0.42 * * *(-4.25)$ \\
\hline & $\mathrm{R} \& \mathrm{D}$ & $0.69 * *(2.14)$ & $0.21 * *(3.05)$ & $-0.48 * *(-2.12)$ & $0.32 * * *(5)$ \\
\hline & MET & $-0.55(-1.01)$ & $-0.12(-1.58)$ & $0.92(1.06)$ & $0(0.02)$ \\
\hline & TEN & $0.03(0.06)$ & $-0.2 * *(-2.47)$ & $0.9 * *(2.8)$ & $0.11(1.01)$ \\
\hline \multirow[t]{6}{*}{ Control variables } & NETIMP & $-1.76 * * *(-3.42)$ & $-0.07(-0.32)$ & $0.36(0.71)$ & $-0.32 *(-1.99)$ \\
\hline & GDPP & $-5.58(-1.29)$ & $-1.18 * * *(-3.67)$ & $7.35^{* *}(2.7)$ & $-0.43(-1.1)$ \\
\hline & NETCON & $2.16(0.34)$ & $-0.49(-0.79)$ & $-5.07(-0.64)$ & $0.35(0.5)$ \\
\hline & $\mathrm{CO} 2$ & $4.32 * *(2.49)$ & $-0.03(-0.1)$ & $-4.3 * *(-2.35)$ & $0.29(0.62)$ \\
\hline & FOS & $-0.69(-1.46)$ & $0.2(1.54)$ & $0.83(1.54)$ & $0.1(0.8)$ \\
\hline & NUC & $-0.11(-1.23)$ & $0.09 *(1.8)$ & $0.36 * *(2.61)$ & $0.05(1.57)$ \\
\hline $\mathrm{R}^{2}$ & & 0.8958 & 0.8025 & 0.7946 & 0.9125 \\
\hline $\mathrm{F}$ & & 129.91 & 127.37 & 78.3 & 1729.09 \\
\hline
\end{tabular}

$* * *, * *$, and $*$, denote $1 \%, 5 \%$, and $10 \%$ significance level, respectively. $t$ values are given in the blankets. Estimations include both country and time dummies

policy tools to stimulate the bioenergy installed capacity. Considering the total RE, it has been revealed that GRANT, TAX, CERT, POL, REG, and R\&D incentives increase the RE installed capacity.

Table.8 Coefficient sign and significance levels (Fixed Effects)

\begin{tabular}{|c|c|c|c|c|c|}
\hline$\overline{\text { Variables }}$ & & Solar & Bioenergy & Wind & Total RE \\
\hline \multirow{11}{*}{$\begin{array}{l}\text { Explanatory vari- } \\
\text { ables }\end{array}$} & DIR & - & - & + & - \\
\hline & FIT &,$+ *$ &,$+ * *$ & - & + \\
\hline & GRANT & + & - &,$+ * *$ &,$+ * *$ \\
\hline & LOAN & - & + &,$+ * *$ & - \\
\hline & TAX &,$+ *$ &,$+ * * *$ & - &,$+ * *$ \\
\hline & CERT & + &,$+ *$ & + &,$+ * *$ \\
\hline & POL & + & - &,$+ *$ &,$+ * *$ \\
\hline & REG & + & + & - &,$- * * *$ \\
\hline & $\mathrm{R} \& \mathrm{D}$ &,$+ * *$ &,$+ * *$ &,$- * *$ &,$+ * * *$ \\
\hline & MET & - & - & + & + \\
\hline & TEN & + &,$- * *$ &,$+ * *$ & + \\
\hline \multirow[t]{6}{*}{ Control variables } & NETIMP &,$- * * *$ & - & + & + \\
\hline & GDPP & - &,$- * * *$ &,$+ * *$ & - \\
\hline & NETCON & + & - & - & + \\
\hline & $\mathrm{CO} 2$ & - & - &,$- * *$ & + \\
\hline & FOS & - & + & + & + \\
\hline & NUC & - &,$+^{*}$ &,$+ * *$ & + \\
\hline
\end{tabular}

$* * *, * *$, and $*$, denote $1 \%, 5 \%$, and $10 \%$ significance level, respectively
Unlike the expectations, it seems that FIT has no significant effect on the total RE. FIT, however, has positive impact on solar and bioenergy installed capacity. As highlighted by Aquila et.al. (2017), regulatory instability and poorly designed energy policies can turn FITs into expensive incentive. Moreover, if prices are not set correctly, net metering can deprive the cash flow and low prices that do not fully reflect the technology cost will send a negative signal to the industry. It is argued by Aquila et al. (2017) and Zahedi (2010) that the incentives that increase the cost of construction of power plant and support mechanisms that do not have a guarantee of energy purchased by the government (e.g., RPS and quota) cannot be effective in deployment of RE.

Our panel data analysis provides mixed and interesting evidence for policy variables. Based on the empirical results, GRANT, TAX, CERT, POL, and R\&D policies have been effective in promoting the renewable energy. That is to say, among the other group of incentives (see Fig. 1), it is found that fiscal and financial incentives significantly promote the RES-E power capacity. Our results are in line with the results of Liu et al. 2019. Moreover, according to our results, while REG negatively effects the RE installed capacity, FIT, DIR, METER, LOAN, and TEN have no significant effect on RE deployment. Regarding the FITs, if there is no guaranteed network access and long-term agreement, this incentive becomes ineffective mechanism. Moreover, subsidies such as LOAN are seen unstable since they depend 
Table.9 Autoregressive model (Arellano-Bover/BlundellBond GMM estimator)

\begin{tabular}{lllll}
\hline & Solar & Bio-energy & Wind & Total RE \\
\hline RECt-1 & $0.96^{* * *(30.14)}$ & $0.26^{* * *}(7.46)$ & $0.88^{* * *}(14.84)$ & $0.79 * * *(16.47)$ \\
NETIMP & $0.13(1.01)$ & $-0.37 * * *(-7.92)$ & $0.04(0.39)$ & $-0.01(-0.27)$ \\
GDPP & $-0.06(-0.81)$ & $0.19 * * *(8.01)$ & $0.16^{* *}(2.22)$ & $0.14 * * *(4.29)$ \\
NETCON & $0.53(0.83)$ & $2.86^{* * *}(12.63)$ & $-0.44(-0.62)$ & $0.41(1.24)$ \\
CO2 & $-0.55(-0.93)$ & $-2.35^{* * *}(-12.6)$ & $0.09(0.13)$ & $-0.62 * *(-2.03)$ \\
FOS & $0.39 *(1.73)$ & $0.52^{* * *}(7.52)$ & $-0.04(-0,19)$ & $0.18(1.63)$ \\
NUC & $0.01(1.13)$ & $0.04 * * *(9.69)$ & $0.01(0.48)$ & $0.02 * * *(3.46)$ \\
AR $(1)$ & $-6.94 * * *$ & -1.33 & $-9.51 * * *$ & -1.63 \\
AR $(2)$ & -1.19 & 0.2 & 1.04 & -0.31 \\
Sargan & $33.89 * * *$ & $64.97 * * *$ & $21.77 * *$ & $107.70 * * *$ \\
\hline
\end{tabular}

$* * *, * *$, and $*$, denote $1 \%, 5 \%$, and $10 \%$ significance level, respectively on the government budget, but TAX makes RE investments attractive, especially in countries with high tax burden. Our findings are similar to Nicolini and Tavoni (2017) however contradict with results of Jenner et al. (2013), Kilinc-Ata (2016) and Bolkesjø et al. (2014).

Assuming there is one lag, autoregressive model regression results will be as shown in Table 9. As expected, installed renewable capacity in previous period positively affects the RE capacity in the current period. In dynamic panel model, $\mathrm{REC}_{\mathrm{t}-1}$ stands for the previous year installed capacity of the RE. Moreover, high level of tariffs at time (t-1) period is positively linked to larger amount of installed RES-E capacity at time $(\mathrm{t})$.

Equation 2 is estimated using GMM. Table 9 depicts the results of GMM estimation and presents the relevant test statistics. Sargan test shows that restrictions created as a consequence of use of instruments are valid and therefore overidenfication does not exist.

The test for autocorrelation in the differenced error term $\mathrm{AR}(1)$ is significant and rejects the null hypothesis, following standard expectations for GMM model and suggesting that autocorrelation does not exist.

In examining $25 \mathrm{EU}$ countries and Turkey, our results indicate that the lagged dependent variable $\mathrm{REC}_{\mathrm{t}-1}$ is positive and statistically significant at the $1 \%$ level, indicating that high $\mathrm{REC}_{\mathrm{t}-1}$ does occur continuously from the past to the future for all kind of RE sources installed capacity. As reported in Table 9, while GDPP and NUC stimulate the $\mathrm{RE}, \mathrm{CO}_{2}$ decreases the total $\mathrm{RE}$ capacity. Interestingly, $\mathrm{CO}_{2}$ displays a negative and significant coefficient, indicating that increasing emissions do not pose an important driver for RE deployment. This result shows that countries prefer cheap fossil fuels to RE in energy utilization and/or mitigating GHGs has not been adequately integrated into RE policies in EU. Economic growth generates output increase that leads more energy consumption. As expected, our results reveal that GDPP positively affect the RE development: higher level of GDPP corresponds to larger amount of installed RES-E capacity. Countries with high national income give more importance to environmental problems and RE deployment than low-income countries. Moreover, higher fossil fuel and nuclear power consumption (substitute variables) stimulate the installed RE capacity. The effects of primary energy sources (such as coal, oil, and natural gas), overall energy consumption, and nuclear power are considerably significant, which is in line with the higher RE deployment. Our results are according to the previous studies such as Marques and Fuinhas (2011a), Gan and Smith 2011, Ackah and Kizys (2015), who found GDP to be important for RE deployment. Contrary to these studies, we find the effect of a national income to be positive. Moreover, our results contradict with the Bengochea and Faet (2012) who found $\mathrm{CO}_{2}$ to be positive for development of RE installed capacity.

\section{Conclusions}

The purpose of this paper is to investigate the effect of the RE incentive instruments on the installed RES-E capacity in 25 EU countries and Turkey during the period of 2000-2018. We set up a panel data set for each RE sources and total RE, considering 11 different incentive policy distinctions. Our analysis differs from previous studies because this is the first paper to analyze the effect of "net metering" instrument on installed RE capacity. Moreover, we have estimated both panel fixed effect and dynamic panel by employing a much larger panel data set and then the previous studies in the literature.

Our results display varied effects of RE incentive schemes on different kinds of RES-E for the countries analyzed. Within this framework, TAX, GRANTS, and R\&D policies are found to be most effective tools for RE deployment in analyzed countries. This implies that among the others, fiscal and financial instruments are generally more effective 
than other kind of incentive tools in energy sector. This is because such incentives reduce the installation and operation cost of power plants. Moreover, market-based incentives such as certificates and POL design also have enhancing effect on incentivized RES-E capacity. Our results reveal that the RE policies in general have contributed to RE capacity expansion; however, net metering, DIR, and loan have no desired influence on the RE deployment. Since the effects of infrastructure investments will be seen in the long term, the effect of DIR may have been meaningless. Like loan and net metering, FIT has no significant effect on total RE except for bioenergy and solar. The amount of the expenditures and the significance of policies might not be high enough to stimulate the development of RES-E. Furthermore, regulations and the direct investments create deterrent impact on RES-E capacity. It seems that regulation does not ensure reliable and long-term signal for RE investors. Our results highlight the importance of RE incentive tools that will reduce the cost of RE investments in terms of the success of RE mechanisms. In addition, all RE incentive mechanisms should be supported by transparent, stable, and effectively designed policies. Efficient policy design should also consider which of the incentives are compatible or supportive of each design.

Dynamic panel estimations indicate that capacity of $\mathrm{RE}$ in the previous period has positive and significant stimulating effect on the current RE capacity. Moreover, our estimation results highlight that fossil energy consumption, nuclear energy, and GDP are important drivers of the RE deployment while net import (energy security) and $\mathrm{CO}_{2}$ emissions are not. Our results show that the fossil fuel lobby is not very effective and concerns about nuclear power are quite strong in analyzed countries. Interestingly, the increase in GHG emissions cannot create a strong incentive for RE investments in the analyzed counties. Moreover, richer countries are in a better position in the field of green energy transformation. The fact that RE technologies have relatively high cost and cannot compete with traditional energy technologies without any supporting policies may have been effective in the emergence of this result. These results are largely in line with the results of the panel fixed effect estimation.

Our findings reveal important policy implications. Since financial and market-based incentives are found to be quite effective, these incentives should be applied more widely, especially in countries that have not adopted them yet. In this regard, the inefficient incentives (such as DIR or loan) should be phased out because of the limited financial opportunities, especially in this crisis period or these incentives should be reformulated in order to overcome market failures and barriers. However, it should be noted that some policy measures (e.g., loan and direct investment, regulation) are found to be effective only for some specific RE sources; governments can prefer to adopt different incentive schemes for different RE sources. Furthermore, our results highlight that technology-push policies pose critical role in expansion of RE in the energy market. Governments should spend much more on the innovation projects. Moreover, policy makers should provide highly reliable, consistent, and transparent environment to attract the investors to the RE sector. Skewed regulatory framework such as delays and bureaucracy can hamper the penetration of RE into energy market. There is an urgent need for an investment environment which promotes investments and lowers the risk in the RE sector.

Our empirical results highlight that increasing $\mathrm{CO}_{2}$ emissions is not an important factor to the development of RES-E in EU countries. This finding points out that economic concerns are dominant than environmental awareness and EU should adopt more stringent regulations that stimulates RE development. In this context, governments should adopt rationally RE policies that decreases uncertainty and vagueness in energy markets and reduces the cost of RE power plant investments (instruction and/or operation cost).

Last but not least, we suggest that Turkey should start to implement incentive mechanisms which are found to be effective on the RE deployment in the EU countries. Adoption of these RE incentives by Turkey may contribute to full membership process.

Although our study provides insight into which incentive mechanisms are effective or not, it does not provide information about underlying reasons. Moreover, since RE incentive policies do not have a long history, the availability of data was another limitation of our study. We were unable to include qualitative data on how renewable energy incentives were implemented and under which conditions by policy makers in each country. We only focused on whether the relevant incentive was applied or not. This situation constitutes another limitation of our study as well. Hence, there is still further empirical research to be done on the efficacy of the EU countries' incentive policies on the RE capacity. For example, in order to determine reasons behind the failure of implemented policies, additional research projects should be conducted on firm level. Further empirical research could also examine whether specific incentive policies are more effective at promoting RES-E capacity for different RE sources such as wind, solar, or bioenergy. Moreover, it can be expected that the impact of RE policy schemes is not strong due to the fact that hydropower is not incentivized. Therefore, future research should investigate the results of incentives on both hydro-included and hydro-excluded RES-E capacity expansion for a better understanding of this issue. 


\section{Appendix}

Table.10 Correlation matrix

\begin{tabular}{lllllll}
\hline & NETIMP & GDPP & NETCON & CO2 & FOS & NUC \\
\hline NETIMP & 1 & & & & & \\
GDPP & 0,684 & 1 & & & & \\
NETCON & 0,638 & 0,812 & 1 & & & \\
CO2 & 0,469 & 0,551 & 0,623 & 1 & & \\
FOS & $-0,068$ & $-0,151$ & $-0,351$ & 0,40 & 1 & \\
NUC & 0,045 & $-0,003$ & 0,239 & $-0,017$ & $-0,43$ & 1 \\
\hline
\end{tabular}

Own elaborations

Author contribution Gulden Boluk carried out the investigation, literature review, conceptualization, supervision, visualization, and writing of the original draft. Ramazan Kaplan performed the data collecting and methodology.

Data availability Not applicable.

\section{Declarations}

Ethics approval and consent to participate Not applicable.

Consent for publication Not applicable.

Conflict of interest The authors declare no competing interests.

\section{References}

Abolhosseini S, Heshmati A (2014) The main support mechanisms to finance renewable energy development. Renew Sust Energ Rev 40:876-885

Ackah I, Kizys R (2015) Green growth in oil producing African countries: a panel data analysis of renewable energy demand. Renew Sustain Energ Rev 50:1157-1166

Aguirre M, Ibikunle G (2014) Determinants of renewable energy growth: a global sample analysis. Energy Policy 69:374-384

Al-mulali U, Tang C, Ozturk I (2015) Estimating the environmental Kuznets Curve hypothesis: evidence from Latin America and the Caribbean countries. Renew Sust Energ Rev 50:918-924

Al-mulali U, Solarin SA, Sheau-Ting L, Ozturk I (2016) Does moving towards renewable energy cause water and land inefficiency? An empirical investigation. Energy Policy 93:303-314

Aquila G, Pamplona EO, de Queiroz AR, Junior PR, Fonseca MN (2017) An overview of incentive policies for the expansion of renewable energy generation in electricity power systems and the Brazilian experience. Renew Sust Energ Rev 70:1090-1098

Arellano M, Bover O (1995) Another look at the instrumental variables estimation of error components models. J Econ 68:29-51

Assmann D, Laumanns U, Uh D (2006) Renewable Energy: A Global Review of Technologies, Policies and Martkets. Eartscan, London
Baltagi BH (2013) Econometric Analysis of Panel Data, 6th edn. Springer, USA

Baltagi BH, Wu PX (1999) Unequally spaced panel data regressions with AR(1) disturbance. Economet Theor 15(6):814-823

Beck KA, Joshi P (2015) An analysis of the environmental Kuznets curve for carbon dioxide emissions: evidence for OECD and nonOECD countries. Eur J Sustain Dev 4(3):33-45

Bengochea A, Faet O (2012) Renewable energies and CO2 emissions in the European Union. Energy Sources B: Econ. Plan Policy 7(2):121-130

Bhargava A, Franzini L, Narendranathan W (1982) Serial correlation and the fixed effects model. Rev Econ Stud 49(4):533-549

Bird L, Bolinger M, Gagliano T, Wiser R, Brown M, Parsons B (2005) Policies and market factors driving wind power development in the United States. Energy Policy 33(11):1397-1407

Blundell R, Bond S (1998) Initial conditions and moment restrictions in dynamic panel data models. J Econ 87:115-143

Bolkesjø TF, Eltvig PT, Nygaard E (2014) An econometric analysis of support scheme effects on renewable energy investments in Europe. Energy Procedia 58:2-8

Bölük G (2013) Renewable energy: policy issues and economic implications in Turkey. Int J Energy Econ Policy 3(153-167):2013

Borawski P, Bełdycka-Borawska A, Szymanska EJ, Jankowski KJ, Dubis B, Dunn JW (2019) Development of renewable energy sources market and biofuels in The European Union. J Clean Prod 228:467-484

Carley S (2009) State renewable energy electricity policies: an empirical evaluation of effectiveness. Energy Policy 37:3071-3081

Ding J, Somani A (2010) A Long-Term Investment Planning Model for Mixed Energy Infrastructure Integrated with Renewable Energy, 2010 IEEE Green Technologies Conference, Grapevine, TX, 2010, 1-10. Retrieved 03 August 2020 from, https://ieeexplore. ieee. $\mathrm{org} / \mathrm{stamp} / \mathrm{stamp} . j \mathrm{sp}$ ?tp $=$ \&arnumber $=5453785$

Dong CG (2012) Feed-in tariff vs. renewable portfolio standard: an empirical test of their relative effectiveness in promoting wind capacity development. Energy Policy 42:476-485

EC (2009) Directive 2003/30/EC 2009/28/EC of the European Parliament and of the Council of 23 April 2009 on the promotion of the use of energy from renewable sources and amending and subsequently repealing Directives 2001/77/EC. (05.07.2020).

EC (2018) Directive (EU) 2018/2002 of the European Parliament and of the Council of 11 December 2018 amending Directive 2012/27/ EU on energy efficiency. (17.06.2020).

EC (2020) Renewable Energy in EU in 2018, Eurostat News release, 17/2020, 23 January 2020. Retrieved 10 May 2020 from, https:// ec.europa.eu/eurostat/documents/2995521/10335438/8-23012 020-AP-EN.pdf/292cf2e5-8870-4525-7ad7-188864ba0c29\#: : text $=\mathrm{In} \% 202018 \% 2 \mathrm{C} \% 20$ the $\% 20$ share $\% 20$ of, which $\% 20$ the $\%$ 20data\%20are\%20available 
Erdin C, Ozkaya G (2019) Turkey's 2023 Energy Strategies and Investment Opportunities for Renewable Energy Sources: Site Selection Based on ELECTRE. Sustainability 11(2136):1-23

Frees EW (1995) Assessing cross-sectional correlation in panel data. J Econ 69:393-414

Friedman M (1937) The use of ranks to avoid the assumption of normality implicit in the analysis of variance. J Am Stat Assoc 32:675-701

Gan JB, Smith CT (2011) Drivers for renewable energy: a comparison among OECD countries. Biomass Bioenergy 35(11):4497-4503

Harjanne A, Korhonen JM (2019) Abandoning the concept of renewable energy. Energy Policy 127:330-340

Hair J (2010) Multivariate Data Analysis: A Global Perspective (7th ed.). Pearson Education, Upper Saddle River, NJ, London

Hayakawa K (2017) Unit root test for short panels with serially correlated errors. Commun Stat-Theory Methods 46(8):3891-3900

He Z-X, Xu S-C, Li Q-B, Zhao B 2(018) Factors that influence renewable energy technological innovation in China: a dynamic panel approach. Sustainability 10:124

IEA (2018) International Energy Agency (IEA). Retrieved 4 April 2020 from, https://www.iea.org/data-and-statistics/data-tables/?count ry $=$ EU28\&energy $=$ Electricity \&year $=2018$

IEA (2020) International Energy Agency (IEA), The impact of the Covid-19 crisis on clean energy progress. Retrieved 9 August 2020 from https://www.iea.org/articles/the-impact-of-the-covid19-crisis-on-clean-energy-progress

Ioan B, Kumaran RH, Larissa B, Anca N, Lucian G, Gheorghe F, Horia T, Ioan B, Mircea-Iosif R (2020) A panel data analysis on sustainable economic growth in India, Brazil and Romania. J Risk Finance Manage 13(8): 170

IRENA (2018) Renewable Energy Policies in a Time of Transition. Retrieved 2 September 2020 from https://www.irena.org/-/ media/Files/IRENA/Agency/Publication/2018/Apr/IRENA_ IEA_REN21_Policies_2018

Irfan M, Zhao Z-Y, Rehman A, Ozturk I, Li H (2021) Consumers' intention-based influence factors of renewable energy adoption in Pakistan: a structural equation modeling approach. Environ Sci Pollut Res 28:432-445

Jenner S, Groba F, Indvik J (2013) Assessing the strength and effectiveness of renewable electricity feed-in tariffs in European Union countries. Energy Policy 52:385-401

Johnstone N, Haščič I, Popp D (2010) Renewable energy policies and technological innovation: evidence based on patent counts. Environ Resour Econ 45:133-155

JRC (2019) Joint Research Center (JRC). Fossil CO2 and GHG emissions of all world countries, 2019 report. Retrieved 8November 2020 from, https://edgar.jrc.ec.europa.eu/overview.php?v= booklet 2019

Kilinc-Ata N (2016) The evaluation of renewable energy policies across EU countries and US states: an econometric approach. Energ Sustain Dev 31:83-90

Kim E, Heo E (2016) Analysis on the effects of renewable policies in OECD countries using dynamic panel model. Environ Resour Econ Rev 25(2):229-253

Kukenova M, Monteiro J-A (2008) Spatial dynamic panel model and system GMM: a Monte Carlo investigation, MPRA paper no: 14319. Retrieved 7 July 2021 from, https://mpra.ub.uni-muenc hen.de/14319/2/MPRA_paper_14319.pdf

Li J, Zhang X, Ali S, Khan Z (2020) Eco-innovation and energy productivity: New determinants of renewable energy consumption. J Environ Manag 271:111028

Lipp J (2007) Lessons for effective renewable electricity policy from Denmark, Germany, and United Kingdom. Energy Policy 34(11):5481-5495

Liu W, Zhang X, Feng S (2019) Does renewable energy policy work? Evidence from a panel data analysis. Renew Energy 135:635-642
Marguez AC, Fuinhas JA, Pereira DS (2019) The dynamics of the short-run and long-run effects of public policies supporting renewable energy: a comparative study of installed capacity and electricity generation. Econ Analy Pol 63:188-206

Marques AC, Fuinhas JA (2011a) Drivers promoting renewable energy: a dynamic panel approach. Renew Sust Energ Rev 15:1601-1608

Marques AC, Fuinhas JA (2011b) Drivers promoting renewable energy: a dynamic panel approach. Renew. Sustain. Energ Rev 15:1601-1608

Marques AC, Fuinhas JA (2012) Are public policies towards renewables successful? Evidence from European countries. Renew Energy 44:109-118

Marques AC, Fuinhas JA, Manso JRP (2010) Motivations driving renewable energy in European countries: a panel data approach. Energy Policy 38:6877-6885

Menz FC, Vachon S (2006) The effectiveness of different policy regimes for promoting wind power: experiences from the states. Energy Policy 34(14):1786-1796

Mihaylov M, Radulescu R, Razo-Zapata I, Jurado S, Arco L, Avellana N, Now A (2019) Comparing stakeholder incentives across state-of-the-art renewable support mechanisms. Renew Energy 131:689-699

Mitchell C, Bauknecht D, Connor PM (2006) Effectiveness through risk reduction: a comparison of the renewable obligation in England and Wales and the feed-in system in Germany. Energy Policy 34(3):297-305

Murshed M (2021) Can regional trade integration facilitate renewable energy transition to ensure energy sustainability in South Asia? Energy Rep 7:808-821

Murshed M, Chadni MH, Ferdaus J (2020) Does ICT trade facilitate renewable energy transition and environmental sustainability? Evidence from Bangladesh, India, Pakistan, Sri Lanka, Nepal and Maldives. Energ Ecol Environ 5(6):470-495

Murshed M, Ahmed R, Kumpamool C., Bassim M, Elheddad M (2021) The effects of regional trade integration and renewable energy transition on environmental quality: evidence from South Asian neighbors. Buss Strat Environ, 1-17.

Nicolini M, Tavoni M (2017) Are renewable energy subsidies effective? Evidence from Europe. Renew Sust Energ Rev 74:412-423

OECD (2017) The empirics of enabling investment and innovation in renewable energy, OECD Environment Working Papers No:123. Retrieved 7 September 2020 from, https://www.oecd-ilibrary. org/docserver/67d221b8-en.pdf?expires $=1618311190 \& \mathrm{id}=\mathrm{id} \&$ accname $=$ guest $\&$ checksum $=74 \mathrm{E} 8 \mathrm{~A} 680 \mathrm{E} 080 \mathrm{~F} 7684 \mathrm{AE} 3 \mathrm{AA} 8 \mathrm{C} 6$ 0E3F8FD

Pesaran MH (2007) A simple panel unit root test in the presence of cross-section dependence. J Appl Econ 22(2):265-312

Pfeiffer B, Mulder P (2013) Explaining the diffusion of renewable energy technology in developing countries. Energy Econ 40:285-296

Polzin F, Migendt M, Täube FA, Flatow P (2015) Public policy influence on renewable energy investments - a panel data study across OECD countries. Energy Policy 80:98-111

Popp D, Hascic I, Medhi N (2011) Technology and the diffusion of renewable energy. Energ Econ 33:648-662

PWC (2012) Price Waterhaouse Coopers. Retrieved 5 September 2020 from https://www.pwc.com.tr/tr/publications/industrial/energy/ assets/renewable-report-11-april-2012.pdf

REN 21 (2020) Renewables 2020, Global Status Report,. Rertieved 4 March 2021 from, https://www.ren21.net/wp-content/uploads/ 2019/05/gsr_2020_full_report_en.pdf

REN21 (2019) Renewables 2019, Global Status Report. Retrieved 11 November 2020 from, https://www.ren21.net/wp-content/uploa ds/2019/05/gsr_2019_full_report_en.pdf 
Shrimali G, Kniefel J (2011) Are government policies effective in promoting deployment of renewable electricity resources? Energy Policy 39:4726-47411

UN (2021) Goal 7: Ensure access to affordable, reliable, sustainable and modern energy. Retrived 7 September 2021 from, https:// unric.org/en/sdg-7/(07.09.2021).

UNFCC (2020) The Paris Agreement, United Nations Framework on Climate Change (UNFCC). Retrieved 10 Fabruary 2021 from, https://unfccc.int/process-and-meetings/the-paris-agreement/theparis-agreement

Verbruggen A (2004) Tradable green certificates in Flanders (Belgium). Energy Policy 32(2):165-176

Wang Q, Zhan L (2019) Assessing the sustainability of renewable energy: an empirical analysis of selected 18 European countries. Sci Total Environ 692:529-545

Wang Q, Guo J, Li R (2022) Official development assistance and carbon emissions of recipient countries: A dynamic panel threshold analysis for low- and lower-middle-income countries. Sustain Prod Consum 29:158-170
WB (2019) Putting a Price on Carbon with a tax, World Bank (WB). Retrieved 5 November 2020 from, https://www.worldbank.org/ content/dam/Worldbank/document/Climate/background-note_ carbon-tax.pdf

Wüstenhagen R, Bilharz M (2006) Green energy market development in Germany: effective public policy and emerging customer demand. Energy Policy 34(13):1681-1696

Zahedi A (2010) A review on feed-in tariff in Australian, what is now and what it should be. Renew Sust Energ Rev 14:3252-3355

Zhang F (2013) How fit are Feed-in tariff policies: evidence from the European wind market, World Bank, Policy Research Working Paper, No:6376. Retrieved 5 December 2020 from, https://openk nowledge.worldbank.org/bitstream/handle/10986/13185/wps63 76.pdf? sequence $=1 \&$ is Allowed $=\mathrm{y}$

Publisher's note Springer Nature remains neutral with regard to jurisdictional claims in published maps and institutional affiliations. 